\title{
The Vös'as', the Udmurt Sacrificial Priest: An Old Task for Young Men ${ }^{1}$
}

\author{
EVA TOULOUZE \\ INALCO (Paris) \& University of Tartu \\ LIIVO NIGLAS \\ University of Tartu
}

\begin{abstract}
In the Udmurt diaspora of Northern Bashkortostan the traditional Udmurt religion is very much alive: it is part of the villagers' everyday life. Rituals are regularly held both at the village level and in the wider community, composed of several villages, and they involve the whole population. This article focuses on the key figure in Udmurt ritual: the sacrificial priest, called the vös'as', and attempts to sketch a pattern of function-performing and transmission, taking into account the slightly varying practice in two local groups of villages. It also reflects on its historical perspective in a Finno-Ugric context in which the practice of ethnic religions is often seen and/or used as a marker of ethnicity.
\end{abstract}

Key words: sacrificial priest, ritual, Udmurt religion, transmission, ethnicity

The Udmurt are a people who speak a Finno-Ugric language in the Volga region. Since 1920 most Udmurt have lived in an administrative region, now a Republic, but there are Udmurt communities in the neighbouring regions, some of them the descendants of migrants who have settled in Muslim areas since the 17th and mostly in the 18th centuries (Minniyakhmetova 1995, 332). Before the arrival of the Russians, and for some time afterwards, the Udmurt practised an agrarian religion based on animism. Although the Udmurt who remained in their core territory had converted to Orthodoxy by 1765 , it is particularly interesting to follow the religious situations in areas where ethnic religions were able to persist without interference until the Soviet period. They are still very much alive at the beginning of the 21st century.

As in most traditions, rituals occupy a highly significant place in the Udmurts' lives. The main output of any ceremonial action was (according

1 This research has been funded by Estonian Research Council (PUT590). 
to ethnographers ${ }^{2}$ ), and is still the cooking of a porridge made of lamb broth, crops, and lamb. In some cases the ceremony can be performed by the male head of the family, while in others - important calendar feasts and seasonal agricultural turning points - the ritual is to be led by a specialist. The authors' fieldwork assists in ascertaining what still exists, what has disappeared, and what has changed.

While previous research has mainly focused on reconstruction - attempting to ascertain the details of the rituals before modernity - our goal is to focus on the current practice of this peculiar form of worship, and to analyse how the population understands it. We intend to study a key figure in the perpetuation of the tradition, the sacrificial priest, for in the context of urbanisation and rural exodus transmission is a core question. In a wider context the question of the possible use of ethnic religion as an identity marker and the priest's possible role in this must also be considered.

Very few of these practices have resisted the successive efforts of evangelisation and sovietisation in Udmurtia. As Ranus Sadikov, an Udmurt ethnographer who specialises in this region, emphasises, the disruption of the village community by collectivisation has seriously transformed collective life in the countryside (Sadikov 2012,48), in Udmurtia as well as in the further-flung Turkic regions. There are still places where tradition has shown itself more resilient. One of these is Bashkortostan, where Udmurt peasant communities practise forms of worship as ethnographers described them in the 19th century.

This is easily explained. In Udmurtia the communities had to face evangelisation and then collectivisation, the first imposing a new and enduring way of thinking about oneself in the world, the second revolutionising the way people related to each other in everyday life. In Bashkortostan the first disruptive phase did not take place. The effects of collectivisation were similar in Bashkortostan as elsewhere: the basis of community life changed, and anti-religious ideology was spread through school, the army, and state institutions, while more or less active repression led to the fading of the Udmurts' traditional mental world. However, the areas they inhabited were totally rural and remote, and they were able to retain much of their religion.

Contemporary scholars have emphasised the persistence of Udmurt rituals in this region: Tatiana Minniyakhmetova and Ranus Sadikov (1973), themselves natives of Northern Bashkortostan, have defended doctoral

2 Among others, Pervukhin 1888, Aptiev 1891, 1892, Holmberg 1914. 
dissertations and written many studies about them in their current forms, and have described rituals in continuity that have created a corpus, based both on fieldwork and on older literature, whose main emphasis is on the beginning of the 20th century, a period in which tradition was still strong and modernity had not yet penetrated. Nevertheless, external research on these questions is still practically non-existent: although Finnish (Kirsti Mäkela, Seppo Lallukka) and Hungarian researchers (Boglárka Mácsai, Zoltán Nagy) have conducted fieldwork in the region, their findings are still to be published. In the present article we reflect on what we have witnessed, while concentrating on the key role of the sacrificial priest.

\section{Is the $\mathrm{Udmurt}$ religion a religion?}

As a general introduction, is it proper to call what the Udmurt call 'Udmurt oskon' ('Udmurt religion') a religion? We shall not develop this point, but we would like to pinpoint a terminological confusion that is difficult to unravel because of the lack of proper concepts in our toolbox.

The kind of practice we shall study is usually called 'paganism' in Russia. The main problem with the term 'pagan' lies in the fact that it was originally used in opposition to 'Christian'; scholars prefer to approach the phenomenon from a more neutral starting point. Moreover, the word 'pagan' contains other implicit features that do not fit the fluid and situative object of our study: a developed and fixed mythology; a sophisticated polytheism; and no explicit connection with nature. However, the term has been integrated into the discourse as an objective scientific category.

We might use a term from both anthropology and folklore studies: 'belief' in a formalised and dogmatic system as opposed to religion; but 'belief' is also somewhat problematic, for it implies the conscious act of believing. In spite of what is suggested by Christianity's dominance, not every 'belief system' is based on belief. A 'credo' is rather a peculiarity of monotheistic world religions such as Judaism, Islam, and Christianity. Faith and belief are quite improper concepts in many other systems, where the propositional dimension is not articulated into a rigid system. These notions have been imposed on the natives by missionaries, who as professionals could only interpret the unfamiliar by using familiar categories: their thinking habits and their languages did not and do not provide them with appropriate tools to understand the realities they discovered. At the same time, these categories have been accepted and interiorised by the natives themselves (Asad 1993): in contact situations, speaking a language that was not theirs, 
they domesticated the conceptual tools introduced by the 'other'. They have become weapons: even if they did not fit theoretically, they could still be pragmatically and advantageously used. This is the case with the Udmurt, who have adopted the term $u d m u r t$ vera, which can be directly translated as 'Udmurt faith', in contrast to 3 uč vera, 'Russian faith' (Orthodox Christianity) and biger vera 'Tatar faith' (Islam).

We thus face the challenge of expressing something without the appropriate conceptual tools. We have been tempted by the concept of spirituality, as used by Hann $(2007,387)$, but even this term is critical and we shall not use it in this article, for the boundary between the spiritual and the profane is somewhat nebulous. Here, moreover, the practice consists in everyday common actions in the countryside - the slaughtering of animals, cooking, and eating, although they are encompassed in a framework that makes them sacred and gives them place, time, performers, words, and gestures. In conclusion, we are forced to compromise and use the unsatisfactory term 'religion'.

\section{The Udmurt religious world in Bashkortostan at the beginning of the 21st century}

In the second decade of the 21st century peasant life in the Udmurt communities of Northern Bashkortostan is still punctuated by religious gatherings. Continuity is clearly felt, as we observed in our fieldwork in June 2013, 2014, and 2015, as well as in December 2013. We attempted to penetrate the world of Udmurt rituals by attending and filming ceremonies, but also through the mediation of sacrificial priests. We stayed in the Tatyshlinskii raion, in Northern Bashkortostan, and worked in several of the area's villages. Being acquainted with specialist literature, we could observe some changes: many ceremonies that once existed have been forgotten. Others have not faded, while some have been revived, and new forms have also been invented. We have thus merged into a single common practice elements with a different historical status. A comparison with Udmurt religious practice in Udmurtia itself may provide further insights.

Some ceremonies have been forgotten: the Easter ceremony, the Badzhym Nunal (Great Day) festival, ${ }^{3}$ is of very limited importance in Bashkortostan.

3 The Mari have the same kind of holiday, also called the 'Great Day' (kugu keche), corresponding to the Easter period. Its absence or lesser resilience in Bashkortostan may be connected to the absence of Christianity in the area (there is no church in the Tatyshlinskii raion). There are memories of its existence, but it has lost its significance: according to our main informant people used to gather and eat porridge in groups of three or four families; today the celebration is limited to one family, without outsiders, and the head of the family says ritual words over the porridge 
Another example is the spring three-village festival. People remember which villages performed it and with whom, but the tradition is no longer alive in some places, while in other places it has undergone transformation. The tradition of the village ceremony (gurt vös) at the solstice has never been held without interruption. ${ }^{4}$ In general, grass root level ceremonies have been less disrupted by political interference. ${ }^{5}$ The mör vös, the following ceremony in the cycle, one or two weeks after the village event, is observed together by eight to ten villages, and has also been quite resilient. It is the only ceremony of the winter cycle that has been preserved. It was interrupted for seven years in Vilgurt, but was immediately revived when the Soviet Union collapsed. It is now a very public ceremony, attended by a large gathering. It is also attended, as our fieldwork reveals, by 'expatriate' Udmurt, i.e. by Udmurt who work outside the compact Udmurt area but who return for the occasion.

Another ceremony had indeed totally disappeared: the 'country' ceremony, Elen Vös, where all the Udmurt of Bashkortostan and the Perm region used to gather, was attested to in older literature (Sadikov 2008, 46). It rotated between three villages, Varyash, Kirga, and Altaevo, where its memory had faded (Sadikov 2008, 194): as no data are available after the beginning of the 20th century, we may assert that by the beginning of the Soviet period it was no longer being held. It has now been revived and has been held since 2008 in the three villages that hosted it previously (Sadikov 2010, 34), becoming a very popular event.

Having illustrated and sampled the overall framework with these examples from our fieldwork, we shall focus on one key issue. What is the current situation of the specialised bearers of this tradition, the sacrificial priests? ${ }^{6}$ Has their role changed, what is it, who are they, how have they become what they are, and how do they perpetuate themselves? Is this role somehow political? These are the concrete questions we shall attempt to answer.

\section{The central role of the sacrificial priest, the vös'as'}

In the continuation of a tradition the existence of 'people who know' is crucial. In the Udmurt tradition, at the turn of the 19th and 20th centuries,

4 This is true of the spring cycle. However, in winter it is the village ceremony that has disappeared, while the collective ones are still performed.

5 However, people still recall a time when party officials interrupted the ceremony and the contents of the sacrificial cauldrons were thrown on the floor. This did not affect the practice, however: the inhabitants of the village simply changed the location of the ceremony to more hidden places.

6 We use here the expression introduced by Aado Lintrop (Lintrop 2003). 
the ritual specialists, the vös'as', were responsible for larger ceremonies, while the family head (or the kin's elder) could pray in everyday life and at family events (Khrushcheva 1995, 197). ${ }^{7}$

Not everybody could perform at public ceremonies. We know of various kinds of priest: the leader of the ceremony, the vös'as', was responsible for the whole ceremony and recited the prayers; the tylas' was responsible for the fireplace and for throwing whatever was supposed to go there into the fire (pieces of bread, blood, bones, entrails); and the partshas' was responsible for the sacrificial animals (Sadikov 2008, 191). This task-sharing has now disappeared. ${ }^{8}$ We know that until the 1920 s the vös'as' was elected by the assembly of the family heads, ${ }^{9}$ but this is no longer the case. However, in 1928 the Kenesh ${ }^{10}$, the village council, became the enemy, the incarnation of the kulak's power. Moreover, especially after the 1930s, all religious specialists were grouped with Orthodox priests, accused of being exploiters of the people and repressed. All the local leaders were accused of being kulaks and eliminated. While no statistics are available, it is likely that many vös'as' were victims of repression. However, they had a lower public profile than Orthodox priests: they were peasants like everyone else, and many survived. Thus, after the war, the communities had not been totally deprived of their priests.

The main problem lay elsewhere, however: younger people, trained by Soviet education in the cult of modernity and material progress, seldom followed the spiritual traditions of their elders. From this perspective the 1980s and 1990s were years of decline: the older men who had continued to lead ceremonies died without anybody to replace them. Without a priest, worship might disappear. Even if people wanted to continue, they were not able to do so: '[W]e may say that in the 20th century it is only thanks to

\footnotetext{
7 This is still the case. Although it is not the focus of this article, let us mention an event that happened during our fieldwork: Tolya, the son of our host's neighbour was called up, and was to leave on 25th June very early in the morning. The celebration started in the evening, and at about 4 am the father prayed for his son and a ritual porridge was distributed to those who attended.

8 We heard the word partshas' only once, in the mouth of the older vös'as', Nazip, used to mean 'assistant'. Ranus Sadikov, who has spent years studying the Udmurt religion, reacted to this word, for it was the first time he had himself heard it in current speech.

9 This is what Khrushcheva asserts $(1995,197)$. Lintrop argues that, with reference to Udmurtia, in former times the tuno, or wizard, used to appoint the fore-prayers; now the vacant places are filled by voting (Lintrop 1995, 271).

10 The Udmurt word Kenesh was used in the 1920s for the Russian 'Soviet', but it became taboo, and the institution was abolished. There is abundant literature on this issue, especially by Galina Nikitina $(1993,1998)$.
} 
the vös'as' that the tradition of collective ceremonies was preserved. If the priest had no successors, the holding of sacrifices was interrupted' (Sadikov, Danilko 2005, 230-231).

For this reason we focus on this figure, who is so crucial for the survival of the tradition.

\section{The task of the vös'as'}

Today the sacrificial priest's task is varied. He is the master of ceremonies of a fairly complicated ritual that includes several simultaneous actions. He therefore has assistants. The tasks formerly undertaken by particular priests are now entrusted to these assistants. However, the priest must ensure that everybody acts according to the rules. We shall describe his tasks in the simplest ceremony, the village one. ${ }^{11}$ We have chosen to describe Balzjuga, ${ }^{12}$ because it is a tradition that has never been interrupted. Nazip agay , a sacrificial priest for sixty years, who has thoroughly trained his assistants and successor, has continued to conduct it.

Before the event the priest gathers offerings - bread, crops, sacrificial animals, and money. All these items are brought to the venue of the ceremony. Every ceremony starts with an opening ritual, the siz'is'kon, held on the morning of the main ceremony. Porridge is cooked without meat, and only the main priest prays to ask permission to make a sacrifice while holding some porridge in a bowl on a towel and some birch ${ }^{13}$ branches. Then all the people ${ }^{14}$ eat a spoonful of the ritual porridge and continue to eat from the general pot. Only then may the preparations for the sacrificial ritual itself start.

During the first prayer two assistants present the sacrificial animal, a lamb, and 'purify' it before the sacrifice with a birch branch, with which they cut the lamb's throat, while another assistant is ready with a spoon to gather the first blood and to throw it into the fire. He repeats this three times. At the same time the priest prays, holding the bread baked by the former

11 Our description is based on our observation and video recording of the Balzjuga gurt vös' in 2014.

12 Although we have attended two other village ceremonies, in 2014 (Uraz-Gilde) and 2015 (Aribash), these two ceremonies have either been revived in a more elementary shape (UrazGilde) or merged with another form of ceremony, the Keremet vös (Aribash).

13 The branches used in the ceremonies differ according to the season: in spring-summer, they are birch; in winter, fir. Whenever branches are used, the season determines which tree they are taken from.

14 Usually, at this stage, only assistants - and anthropologists - are concerned. 
owners of the sacrificial animal. It must have a coin baked inside it. During the prayer the other assistants kneel and bow when the priest says 'Amin'. Afterwards the sacrificed animal must be skinned and cut into portions.

The priest must then pour salt into the pot, the meat must be thrown into the pot onto the salt, and only then must water be added. At the same time, the crops given by the population must be prepared and the money counted. It takes a long time for the meat to be cooked. The priest then looks for the ritual parts and puts them on a plate, ${ }^{15}$ and recites a prayer over it, holding it as before on a towel and branches, while some assistants separate the meat from the bones, give the audience some bones to chew before throwing them on the fire, and put the meat back into the pots, into which other assistants have meanwhile placed the crops. Their task is physically hard: to stir the porridge in the pots with huge wooden poles until it is ready. Finally, the porridge is distributed to the assembled people, and the priest recites the last prayer in gratitude for the money offerings. The fireplaces are then 'closed' by sweeping them with the birch or fir branches, and all the utensils must be cleaned and packed away. The remains of the porridge are brought back to the village and distributed there to those who were unable to attend.

This is a complex ritual with many concomitant activities, and it is the sacrificial priest who is responsible for the whole.

\section{The transmission of knowledge and the choice of priest}

With the disruption of the rural community in the 1930s, it was clearly impossible to maintain this competence in the framework of the furiously anti-religious collective farm. The formerly elected vös'as' continued in secret, and were solely responsible for the future.

Nazip Sardiev, born in $1930,{ }^{16}$ and today the region's most prestigious and famous vös'as', told us how he became a priest: he was in his twenties, and he had long been an assistant. One of the vös'as' ceased to pray and another died. Then a remaining vös'as' told him: 'Now, son, you will pray.' 'The first time, my hands shook. They decided that it was too soon and postponed it. Next year I passed the test, . .. although my hands still shook. ${ }^{17}$

15 Some particular parts of the animal have been previously marked and will be used in the next prayer: the heart, the head, the liver, a right rib, and the right fore thigh.

16 He worked with horses in the local kolkhoz and never left his village, where he married and had five children (Sadikov, Danilko, 2005, 229). He still lives there.

17 Oral information, 2013. 
He was thus co-opted by a functioning priest, but he had learnt the prayers beforehand only by listening to them for a long time and incorporating his elder's experience.

The problem of transmission is a real concern for Nazip agay (Sadikov, Danilko 2005, 232). ${ }^{18}$ He is today considered the specialist to consult in the entire Udmurt diaspora, and he is often invited to lead ceremonies (Sadikov, Danilko 2005: 232). In the last decade he has concentrated on teaching younger people to provide the communities with priests. As is to be expected, the results are mixed. With some, he believes, it has not worked. With others, it has worked weakly, and with others adequately. ${ }^{19}$

\section{How did he choose the persons to be instructed?}

Several preconditions were to be respected. The conditions about which Nazip agay is strict concern the person of the future vös'as': as in the past, he must be a married man (Lintrop 2002: 44), as must his assistants. They must all be full members of the community - bachelors are not 'whole' and cannot be trusted with such responsibility: 'The scope of peasant society is to reproduce itself. You cannot be an active member if you have not done all you can to fulfil your aim,' explains Sadikov. The second personal criterion is that the person must have an impeccable social profile: priests are not supposed to drink; they should not smoke; and they should be good workers, husbands, and fathers.

Although people in the village marry early, it is much more difficult to find men who do not drink and who are motivated for the task. According to our observations the rule not to smoke is not taken seriously nowadays. Some well-respected and experienced vös'as' actually smoke during breaks in the ceremonies, though not inside the sacrificial space. The choice is still quite limited. Nazip agay therefore ignores some other criteria from earlier times in choosing a vös'as'.

According to ethnographic data only those older than forty can be elected as vös'as' (Sadikov 2008, 191). But Nazip agay does not require any age limit: some years ago, he chose a young man in his late twenties to be

18 Agay is the honorific title which is given to older men. Its meaning in Udmurt is "elder brother, uncle".

19 His assessment is actually based on what he considers to be the only right way to act. Still, in parallel with his tradition, there are other competing traditions: in the neighbouring area of Alga, ceremonies vary in detail, but are considered by Nazip agay as erroneous, while for the local priests, they correspond to their local traditions. 
his successor in his own village; and in the winter prayers we noticed that along with experienced priests in their fifties there were some very young men, who had been assistants in the previous ceremonies. They were 'appointed' by the 'head of the ceremony' (vös' kuz'o), who in this case was not a sacrificial priest, but was still very active in organising the ceremony. The second important criterion on which Nazip agay has compromised is the need for the candidate to have priests among his forebears. If none is found with such forebears, he does not refuse men who lack a priestly 'pedigree'.

\section{How are the candidates trained?}

Training 'methods' today very much follow the traditional pedagogical methods of native societies. They do not rely on verbal expression or theoretical knowledge, but on experience and observation (Ingold 2000, Vallikivi 2011). Nazip himself was trained in the natural way, by staying close to sacrificial priests, seeing them performing, and imitating them. He teaches in the same way: the apprentices are close to him and observe what he does. They are then expected to imitate their master.

One of the central aspects of the priest's work is prayer. Every priest has one prayer, whose core is repeated in every situation, while the introduction and/or the conclusion depend on the aim of the prayer and its place in the ritual. According to tradition the priest had to 'steal' a prayer, which meant that he had to learn it naturally, by hearing it without attempting to memorise it (Sadikov 2008, 192). But very few living priests have learnt their prayers in this way.

Most have learnt them from older people, not orally, but from a written text, or by cutting it from newspapers or journals. ${ }^{20}$ For example, the younger Balzyuga vös'as' gave us two prayers by copying them on our memory stick from his computer. He himself has not yet learnt his prayers by heart: during the ritual he reads them from a paper, as some others do in other villages. Thus, the penetration of written culture can be observed, and it is accepted by Nazip agay. Other priests take over a prayer and introduce changes, adapting them to modernity: this is an old practice: already in the Soviet period vös'as' would pray for tractor drivers and machine operators; today they pray that drug addiction will not spread in the village.

20 In the 1990s and 2000s prayers were published in the local press. 


\section{Perpetuation and transmission: some portraits of $v o ̈ s^{\prime} a s^{\prime}$}

In the Tatyshlinskii raion there are several priests, who are quite different from one another. We have met many of them, but we shall concentrate only on some, whom we have recorded in action and in interview. Let us comment on their journeys.

\section{Balzyuga}

Balzyuga is a small village of 240 inhabitants, homogeneously Udmurt (99\%), with two priests. One is Nazip agay, ${ }^{21}$ who is now 85 and retired. After sixty years as a priest he still has his wits and is willing to share his knowledge widely. He is an old man full of dignity, with intelligent, benevolent, and penetrating eyes. Today he is the primary tradition bearer, and he is unhappy to see his disciples neglecting some of the rules he has attempted to teach them. He often does not hesitate to formulate opinions concerning them we would not dare to repeat. He claims he has trained all the active priests in the region, ${ }^{22}$ and approves more or less of them. His last choice, in his own village, has been to train a young man as his successor, who has already led village ceremonies, both with and without his elder's supervision.

This new vös'as' is a modest, 35 year-old man, Fridman, who considers himself still very much a student. His grandfather was a vös'as'. He is of course married, and has a ten-year old son. He is a respected member of the rural community: he drinks very moderately and only occasionally, and he does not smoke; he has studied music in Udmurtia, so he is a trained singer and musician who teaches in the music school of the neighbouring village of Bigineevo. He reads his prayers throughout the ceremony. This is a huge change from the practice of his elder: for some in the village it is a mistake and it diminishes the gravity of the ceremony, but most are happy to see a young man take this role.

\section{Vil'Gurt}

In Udmurt VIl'gurt means 'new village' and it is the Udmurt name of a village called in Russian Noviye Tatyshly, 'New Tatyshly', as opposed to 'Upper Tatyshly', Verkhniye Tatyshly (the centre of the raion). It is a large

21 He has already been presented in an article (Danilko, Sadikov, 2005).

22 Nevertheless, this assertion is probably only partly justified: at least two of the priests we have interviewed did not mention Nazip agay as having played any part in their training: one learnt from his father, the other from his grandfather. 
village of around six hundred inhabitants, and its importance is due to its being the headquarters of the cooperative, the biggest local employer. It is led by a charismatic leader, Rinat Galiamshin, who, while he was the kolkhoz chairman, created the Udmurt national and cultural centre, which is the equivalent of the local national movement. Later he handed over the post of leader of the enterprise to his son and concentrated on the revival of Udmurt identity in the region, taking advantage of his authority and connections. Thus, Vil'gurt has benefited from the strength of its leader, thanks to whom many necessary facilities have been built in the village, including a new prayer house on the local ceremonial ground. ${ }^{23}$

In the local press and in interviews the workers of the cultural centre and local teachers all acknowledge only one vös'as' in the village, the retired agricultural worker, Salim agay, who makes and sells handmade artefacts. He has a prosperous household. Salim is the 'official' priest to whom foreigners are sent, and who performs in ceremonies as ordered by the cooperative.

He told us that nobody in his family had been a vös'as' and that he was chosen because he was a 'virtuous' member of the community. ${ }^{24}$ Nazip confirmed that he had chosen and trained him, and is not entirely satisfied with the result. When asked about his succession, Salim answered without ambiguity that none of the youngsters was interested.

We were a little surprised to discover when we arrived at the mör vös' in June 2013 that Salim was not leading the ceremony, even though he was present. The leading priest, Rais agay, was a simple cooperative retired worker from the same village; he led the ceremony very confidently, without hesitation, keeping everything under control. He was the one who prayed the introductory siz'is'kon at the opening of the ceremony; in the two following prayers he was accompanied by three other priests (there were four priests, four lambs, and four loaves), among whom was Salim; and the closing prayer was performed by him and Salim. We discovered that the journalists present did not know him at all. He seems to avoid all publicity. However, he has authority, though not unshared, in religious matters. His personality fits the function; he has quick, benevolent, sparkling, and smiling dark blue eyes, and inspires confidence (which, to introduce a personal opinion, Salim does not do as convincingly). However, Salim is the one who acts as vös' $k u z^{\prime} 0$, and organises the material part of the ceremony.

23 He also built a Moshe in the village, although there are only some Muslim individuals. He is quite able to exploit the political context.

24 We do not yet have enough insights into the local society to appreciate the degree of tension that might be connected with being or not being virtuous. 
Nazip also told us that Rais had learnt his job well, and when he watched the video of the ceremony, he approved of many of the decisions he had taken. Nazip complained, however, that Rais had not thanked him for teaching him. The text of Rais's prayer also differed considerably from Nazip's own prayer. We decided to interview Rais, who lives alone with his wife, a Tatar, in a household that seemed more modest than Salim's. We learnt that Rais's father was a vös'as' and that Rais himself had learnt his prayer properly by standing next to him, according to the old tradition of 'stealing' it. Asked about the transmission to younger generations, he answered that he was training his son.

During this interview we could understand part of the tension between him and Nazip: while the latter considered himself the teacher who had given Rais the opportunity to learn the job, Rais placed more importance on what he had learnt from his father, and was attached to his own prayer. The old master is more dogmatic than his pupils, who, in performing ceremonies in slightly different ways, also follow local tradition.

We also met other sacrificial priests in the field, although we did not spend as much time with them as with those previously mentioned. Today the nineteen Udmurt villages in the compact territory of the Tatyshlinskii rayon are traditionally divided into two village groups separated by a river, the Yuk. Both groups have their own rituals, which are almost parallel. The villages hold their ceremonies the same day, but the collective ceremonies are not held on the same day (the Vil'gurt group performs its mör vös a week before the Alga group's event) to allow people to visit the other's ceremony. The Alga group ${ }^{25}$ also performs a slightly more complicated cycle in June and December, because they have not only maintained but developed the principle of the three-village ceremony, with, in both cycles, an eight-village ceremony held one week before the mör vos. The comparison between both mör vös' allows us to identify clear differences in ritual performance, but these will be dealt with in another study. What we wish to emphasise here is the persistence of strongly differing local traditions. ${ }^{26}$ We shall only comment here on some differences in the role of the vös'as'.

The main vös'as' in the Alga group of villages is Evgenii, who works as the main bookkeeper of the Rassvet kolkhoz, based in Nizhnebaltachevo,

25 We call it this for the purpose of this article; this is not a recognised name.

26 The acknowledgement of these peculiarities has led us to a long term project, which is to record all nineteen village ceremonies, so that we do not involuntarily become the means of standardising the ceremonies according to those we have already recorded and left as DVDs with the sacrificial priests. 
where he lives. What is still characteristic of the way the Alga ceremony is led is that Evgenii is very efficiently supported by a sort of 'main' assistant, the vös' $k u z^{\prime} 0$, Farhullah, an older man who is not a priest, but seems to be a knowledgeable and practical guardian of tradition; he is a former village head and has clear authority. He materially organises all the ceremonies, and Evgenii has only to perform his own role, which is to pray and to give all the signals connected with the ceremonial activities. Farhullah prepares all the background: having the grass cut, having the logs ready to make the fire, and making sure the sacrificial animals are in the right place. He is also in charge of 'promoting' sacrificial priests: if one of the appointed vös'as' is absent, he decides who will pray in his stead. There is always a vös kuzo, but in many cases, it is the sacrificial priest, as in Balzjuga; thus, vös'as' and vös kuzo exercise two distinct functions, which are sometimes concentrated in the same person, but sometimes shared between two villagers.

Another difference is that in the Alga group the population brings an offering to the ceremony and gives it personally to the vös'as', who receives it with a personal prayer. In Vilgurt the people simply put the offerings on a bench.

\section{A political leader?}

If we examine the Eastern Udmurt situation within the regional context and extend our observations to other Finno-Ugric communities in the region, we can observe that traditional religions are often used as a powerful ethnic marker (Luehrmann 2011, 42; Leete \& Shabaev 2010, Alybina 2014, 90-91). This is particularly true of the Mari in Mari El. The Mari are the least Christianised of the Volga Finno-Ugric peoples: their religious identity proved most resistant to forced evangelisation, and after the collapse of the Soviet Union the ethnic Mari religion has been powerfully revived (in 200419.4 percent of the Mari considered themselves followers of the Mari religion in more or less syncretistic ways - Sharov 2007, 175). The public discourse around it is thoroughly connected with national identity (Alybina 2014, 91). This is not the case among the Udmurt. In Udmurtia there are only a few villages in which the ethnic religion has been preserved without explicit Christian interference (this does not exclude indirect influences from the general environment, while all over the country there are other manifestations of syncretism in the people's religious practices), which are seen more as a curiosity than as a lighthouse for Udmurt ethnicity. 
Although Mari religion has been institutionalised in Mari $\mathrm{El}^{27}$ with publications, new rituals, and a strong hierarchy including sacrificial priests (Alybina 2014, 92, 98-99), in Bashkortostan the political and identity dimension seems to be reduced to the more or less emotional feelings of particular vös'as', and it never appears in public discourse. Even at the Congress of the Udmurt National Cultural Centre in November 2015, ${ }^{28}$ no mention was made of religious practice during the entire day the Congress lasted, and few priests attended. Their absence shows the almost total disconnection of religious activities and the Udmurt national movement in this area.

The Bashkortostan ceremonies are not accompanied by any public or personal ideological discourse. While analysis clearly shows that they are probably now the only place where communication in Udmurt is guaranteed (because of the rise in mixed marriages, the minority language may no longer be dominant in the family), and thus might be a strong pillar of Udmurt identity, it does not seem to act as such, as least for now. When asked why these ceremonies are important, both sacrificial priests and the lay population simply emphasise the 'natural' link to what the ancestors did: things have to be done, because it is how they have always been done. When asked what happens if one does not attend the ceremonies, answers are hesitant. People look for examples of misfortunes affecting lazy adherents, and usually find them, but this is a reflection of their desire to please the interviewer. This question does not seem relevant: tradition is self-justified by its own existence, without the need to give any foundation through rational arguments.

This is a strength but also a weakness that may in the dangerously near future threaten the very existence of this religious practice. It is a strength because it is an intrinsic part of life that is taken for granted. Even where it is the result of revival or of a recent construction, the aim is to put things right and to re-establish order and balance where there was chaos. No additional meanings are added in the process. This does not mean that the revivers do not intend to enhance ethnic awareness. Usually the impulse for revival comes from the centre: its primus motor is the head of the kolkhoz - later of the Udmurt cultural centre - Rinat Galliamshin, who has initiated the building of prayer houses, the fencing of the sacred places (a new feature of the tradition), and even some village prayers. He usually asks a respected older man, somebody active in local politics, to fetch an older sacrificial priest or his sons and tell them to officiate again, even after breaks

27 Officially, Mari Traditional Religion.

28 Where the authors attended. 
of years or decades. When people are told by influential personalities to organise ceremonies they are obedient, and traditions have thus been started everywhere. In some places local activists have taken over and devoted themselves to these activities (e.g. the Garaev couple in Aribash). In others the involvement has been more mechanical, but the response from the population is unanimously positive, and the new ceremonies have quickly taken root and are massively attended.

However, the lack of an ideological background supporting and accompanying this activity is also a weakness: if the situation becomes critical, there will be no supporting mental framework to maintain it. The language situation, while still very comforting in terms of minority language use and preservation, is already wavering: young Udmurt couples leaving their home area to look for work in other more industrial regions find themselves in the midst of the Russian population and start speaking Russian to their children, even though Udmurt is their mother tongue. They are not supported by an ethnic ideology that will motivate them to raise their children bilingually or multilingually. We therefore have the impression that the situation is aptly comparable to the position of Animism in the face of Christianity or Islam: it is weak, because of the lack of a strong dogma that can withstand pervasive ideologies.

\section{Conclusion}

This short overview is an attempt to decipher the present state of the spiritual world of the Bashkortostan Udmurt, who have been more successful than others in Russia in preserving their old values. Their keeping of their ritual traditions is not led, as our examples show, by a desire to reproduce precisely the ancient practices that have disappeared. Even the most conservative of activists, like Nazip, acknowledge that things change and seek in their own practice to ensure the vitality of the whole system and not to reproduce it mechanically. The differences among vös'as', emphasised also by Lintrop (Lintrop 2002, 54), even on the small scale we chose, reveal real tensions and problems as in all human communities, as well as different ways to be vös'as' and to set ceremonial practices. We may therefore argue that the system is vibrant and that its diversity is its strength, and the presence of younger men among those chosen suggests there is a future for these forms of worship.

In conclusion, we have examined here a core problem in the practice of religion: the role of the key figure in its ritual, with his abilities and 
knowledge, and how this role is being transmitted to younger generations. The vös'as' is an entirely ordinary member of the village community, who is respected and considered 'virtuous', and who takes upon himself the organisation of the community's ritual life. The transmission of this role is possible because being a vös'as' is something that may be learnt, and does not require, at least today, peculiar features or extraordinary knowledge. It is facilitated by the position of the elders in charge of transmission, who have chosen to encourage young people to act as religious leaders. It seems a reasonable adaptation in a wider social context where youth is increasingly challenging old age for prestige in society. However, unlike in other nearby regions, their role as leaders is merely religious, and currently has no political implications.

The elders responsible for Udmurt religion in Bashkortostan have chosen the most reasonable path to allow their religion to be preserved. Nevertheless, the challenges are not in practice itself, but in its context. The Udmurt religion is thoroughly connected to rural life, while rural life itself is threatened by modern ways, by a set of values that relegate the rural to the bottom of social prestige: today, even in the remote villages that are involved in these community rituals, the younger generation is computer and town-oriented and shares networks and entertainments with youngsters all over the world. Will they remain in the village, or will they return to marry and become members of the community, allowing it to thrive? Moreover, the traditional structure of village life is being shattered. In some parts of the country this collapse took place two decades ago. But here the collective farms were successful at the end of the Soviet era, and have been replaced by cooperatives that reproduce the previous model quite closely. While these cooperatives have been able for some years to adapt to the market economy and have achieved good productivity, this well-being is seriously threatened. What will happen if the cooperative fails? It will be important to follow the viability of rural life if the chances of this unique religious practice's survival are to be assessed.

\section{$* * *$}

EVA TOULOUZE, anthropologist, is professor of Finno-Ugric studies in INALCO (Paris) and researcher at the University of Tartu, Department of Ethnology. E-mail: evatoulouze@gmail.com.

LIIVO NIGLAS is an ethnologist at University of Tartu, well-known for his ethnographic movies about the search for identities among indigenous peoples. E-mail: liivon@gmail.com 
Bibliography

Alybina, Tatiana

2014 Vernacular Beliefs and Official Traditional Religion: The position and meaning of the Mari worldview in the current context. - Approaching religion 4 (1), 99-100.

Asad, Talad

1993 Genealogies of Religion: Discipline and Reasons of Power in Christianity and Islam. Baltimore: John Hopkins University Press

Hann, Christian

2007 The Anthropology of Christianity per se. European Journal of Sociology 48 (3), 383-410.

Ingold, Tim

2000 The Perception of the Environment: Essays on Livelihood, Dwelling and Skill. Abingdon-on-Thames: Routledge.

Khrushcheva, Margarita

1995 Folk beliefs in the Udmurt system of the calendar rituals. Mare Kõiva \& Kai Vassiljeva (eds), Folk Belief Today, 192-200. Tartu : ETA, EKI, EKM.

Leete, Art \& Yuri Shabaev

2010 Notes about re-identification of ethnographic groups. Folklore: Electronic Journal of Folklore 46, 169-76.

\section{Lintrop, Aado}

2002 The Spring Prayer Feasts in the Udmurt Village of Varklet-Bodya in Tatarstan. Cosmos 18, 43-55.

2003 Udmurdi usund. Tartu: ERM.

1995 Pagan Sacrificing procedures of the Udmurts. Mare Kõiva \& Kai Vassiljeva (eds), Folk Belief Today, 270-5. Tartu : ETA, EKI, EKM.

\section{Luehrmann, Sonia}

2011 Secularism Soviet Style: Teaching Atheism and Religion in a Volga Republic. Bloomington: Indiana University Press.

\section{Minniyakhmetova, Tatiana}

1999 Ohverdamine Kaama-tagustel udmurtidel. - Mäetagused 9, 50-61. <http://www.folklore.ee/tagused/nr9/minni11.htm 1999>

1995 Eating of beestings as an original calendar rite of the Bashkirian Udmurts. Mare Kõ̃iva \& Kai Vassiljeva (eds), Folk Belief Today, 331-4. Tartu: ETA, EKI, EKM.

\section{Nikitina, Galina}

1993 Sel'skaia obshchina-buskel'v poreformenniy period (1860-1900 gg.). Izhevsk : UdIIYaL UrO RAN. 
1998 Udmurtskaia obshchina v sovetskii period. Izhevsk: UdIIYaL UrO RAN.

\section{Sadikov, Ranus}

2008 Traditsionnie religioznie verovaniia i obriadnost' zakamskikh udmurtov (istoriia i sovremennie tendentsii razvitiia). Ufa: TsEI.

2010 Elen vös' - «molenie stranoi». Zhivaia drevnost' na prostorakh Bashkirii. Vordskem kyl 7, 34-5.

2012 Religioznie verovaniia i obryadnost' Zakamskikh udmurtov (sokhranienie i preemstvernnost' traditsii), Ufa: Nauchny centr RAN.

\section{Sadikov, Ranus \& Elena Danilko}

2005 Udmurtskii zhrets - khranitel' traditsii (vzgliad vizual'nogo antropologa). Galina Nikitina (ed.), Diaspory Uralo-Povilzhiia, 230-3. Izhevsk: UdIIYaL UrO RAN.

\section{Sadikov, Ranus \& Tatiana Minniakhmetova}

2012 Zarubezhnie issledovateli etnografii, fol'klora i iazyka Zakamskikh udmurtov: istoriograficheskii ocherk. - Ezhegodnik finno-ugorskikh issledovanii 4, 49-62.

\section{Sharov, Vladimir}

2007 Mariitsy v Respublike Marii El. Depopulizatsia ili nesovershenstvo perepisi? V. V. Stepanov \& V.A. Tishkov (eds), Etnokulturnii oblik Rossii. Perepis 2002 g., 163-76. Moscow: Nauka.

\section{Toulouze, Eva}

2011 Périple spirituel chez les Oudmourtes avec quelques portraits. Notes de terrain. Études finno-ougriennes 43, 250-64.

\section{Vallikivi, Laur}

2011 Words and Silence: Nenets Reindeer Herders' Conversion to Evangelical Christianity. Unpublished PhD thesis, University of Cambridge. 


\section{Appendix:}

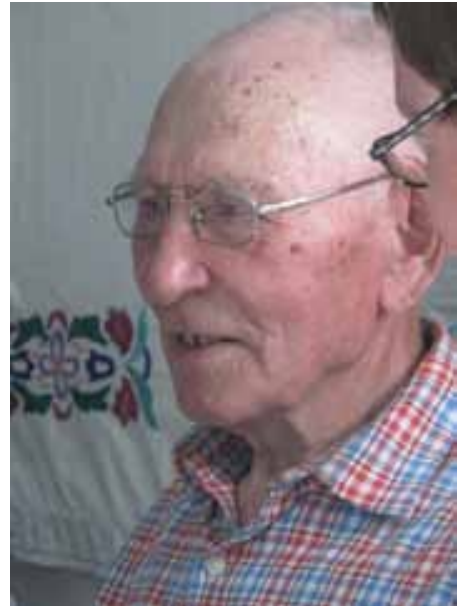

Photo 1: Nazip Sardiev (Photo Eva Toulouze, June 2013)

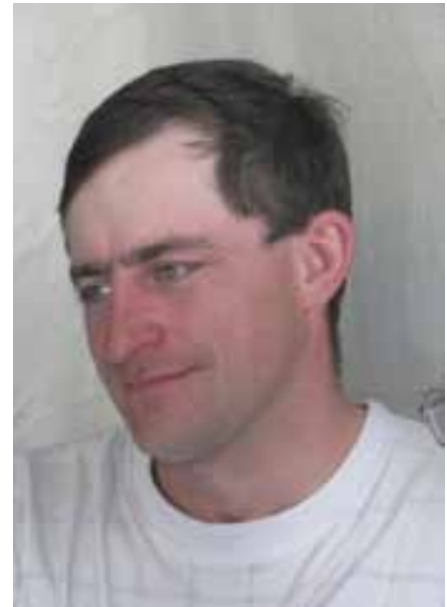

Photo 2: Fridman Habibjanov (Photo Eva Toulouze, June 2013)

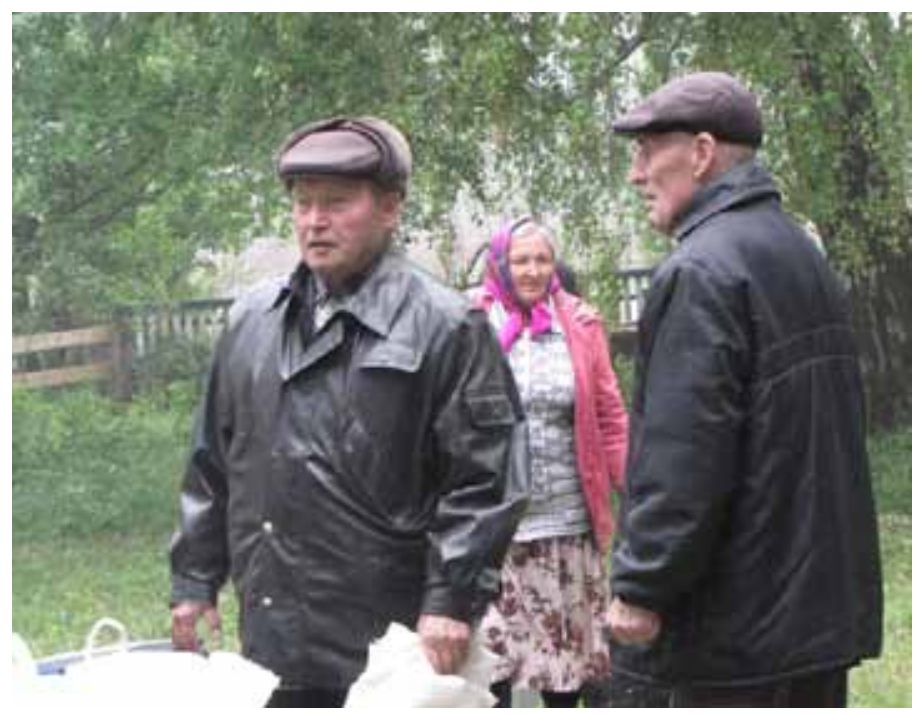

Photo 3: Salim agay (Photo Eva Toulouze at the Vil'gurt mör vös', June 2013) 


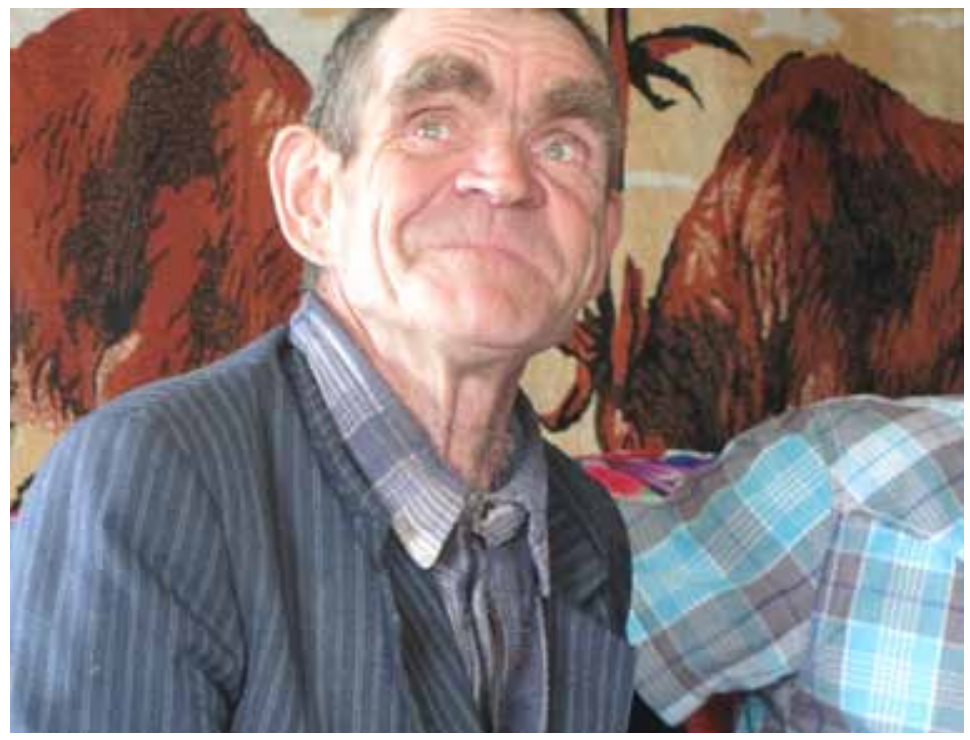

Photo 4: Rais agay (Photo Eva Toulouze, June 2013)

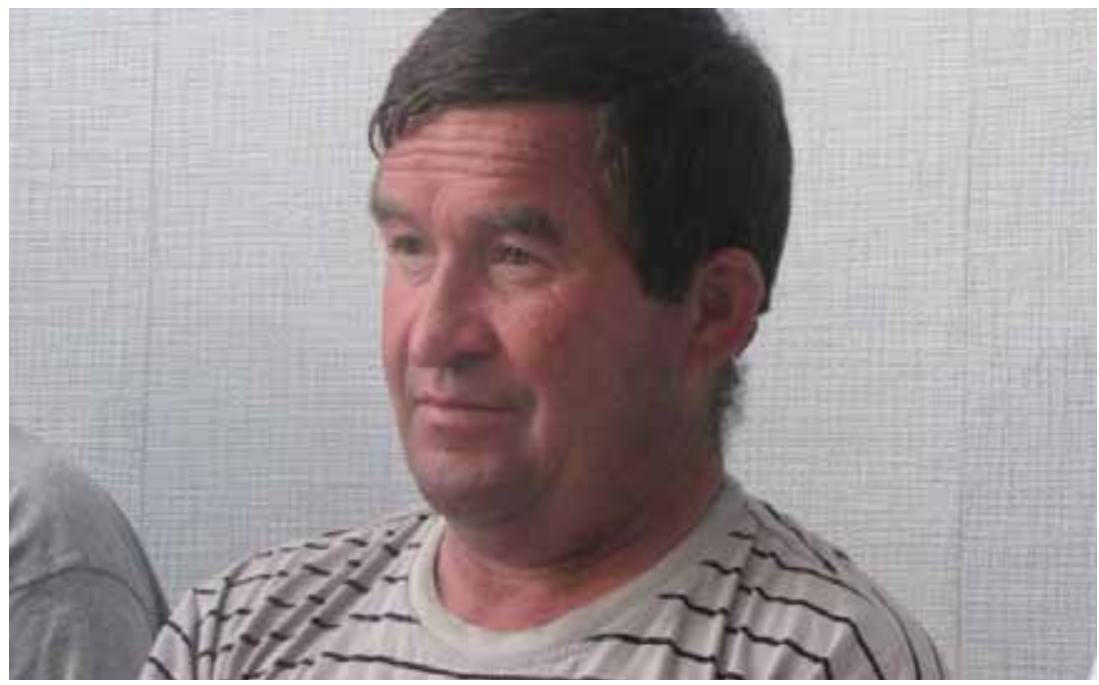

Photo 5: Evgenii (Photo Eva Toulouze, June 2013) 
